\title{
Governance Networks as a Frame for Inter-Demoi Participation and Deliberation
}

\author{
Sørensen, Eva
}

Publication date:

2010

Document Version

Publisher's PDF, also known as Version of record

Citation for published version (APA):

Sørensen, E. (2010). Governance Networks as a Frame for Inter-Demoi Participation and Deliberation. Roskilde Universitet.

\section{General rights}

Copyright and moral rights for the publications made accessible in the public portal are retained by the authors and/or other copyright owners and it is a condition of accessing publications that users recognise and abide by the legal requirements associated with these rights.

- Users may download and print one copy of any publication from the public portal for the purpose of private study or research. - You may not further distribute the material or use it for any profit-making activity or commercial gain.

- You may freely distribute the URL identifying the publication in the public portal.

\section{Take down policy}

If you believe that this document breaches copyright please contact rucforsk@kb.dk providing details, and we will remove access to the work immediately and investigate your claim. 


\title{
Centre for Democratic Network Governance
}

\section{WORKING PAPER SERIES}

\author{
GOVERNANCE NETWORKS AS A FRAME FOR \\ INTER-DEMOI PARTICIPATION AND DELIBERATION \\ EVA SØRENSEN
}

WORKING PAPER 2010:2

CENTRE FOR DEMOCRATIC NETWORK GOVERNANCE

ROSKILDE UNIVERSITY, BUILDING 25, P.O. BOX 260

DK-4000 ROSKILDE, DENMARK

WWW.RUC.DK/DEMNETGOV

JUNE 2010

ISBN : $87-92063-43-8$

ISSN : $1902-0058$ 


\begin{abstract}
By focusing exclusively on the contributions of political participation and deliberation for the enhancement of democratic regulation within the confines of a unitary demos, traditional liberal theories of democracy have overlooked the potential democratic value of political participation and deliberation between demoi. Currently, the need to find ways to increase the democratic quality of inter-demoi interaction is growing rapidly due to the emergence of a pluricentric political system in which cross demoi decision making is more the rule than the exception. Consequently, there is an urgent call for new theories of democracy which are able to identify standards for institutional setups that facilitate inter-demoi participation and deliberation. Governance networks, which represent a part of the challenge posted by the emerging pluricentric system of governance, might prove to be a central means to cope with the new call for democratic regulation across demoi because they represent a means by which to establish weak ties of control and communality between the strong ties that exist within the individual demoi.
\end{abstract}

\title{
1. Introduction
}

Liberal theories of democracy share the view that political participation and deliberation are important because they contribute to the construction of a strong demos through the institutionalization of tight public control over the authorities (Bentham, 1776/1948; Mill, 1820/1937; Dahl, 1989) and/or a strong sense of communality among the citizens (Stuart Mill, 1861/1946; Barber, 1984; Macpherson, 1977; Pateman, 1970). However, liberal theories of democracy have neglected to consider the possible role of participation and deliberation in enhancing democratic control, and sense of communality in enhancing democratic interaction between demoi. This neglect is becoming even more apparent due to the current changes in the way advanced liberal democracies are governed. For the last 250 years, nation state hegemony has been the imaginary point of departure for liberal theories of democracy, this image, which has never mirrored by reality, has now become more and more difficult to uphold due to the development of an increasingly pluricentric political system (Kersbergen and Waarden, 2004) in which processes of societal governance, more often than not, involve more than one demos. This transition from nation state hegemony to pluricentric governance calls for the development 
of new theories of democracy, which provide answers to the question of how inter-demoi governance can be democratically regulated.

In recent years, much attention has been given to the role that networks play and might play in the provision of efficient and effective inter-organizational governance (Kickert, Klijn and Koppenjan, 1997; Rhodes, 1997; Jessop, 1998; Goldsmith and Eggers, 2002; Kettl, 2002; Peters \& Pierre, 2000; Sørensen and Torfing, 2007). The strength of governance networks, it has been said, is their ability to provide flexible coordination between different actors in today's fragmented political systems. Less attention has been directed towards the problems and potentials of networks as a means to enhance democratic governance. The aim of this article is to discuss and analyze the extent to which and how governance networks can function as a means to facilitate democratic inter-demoi participation and deliberation. The first step in this endeavor is to show how liberal theories of democracy have tended to focus on intra-demos participation and deliberation, while giving little or no attention to the democratic quality of the interplay between demoi. Following that, I describe the increasing pluricentric form of governance in advanced liberal democracies. It is argued that governance networks play a central role as mediums for vertical and horizontal coordination between multiple units of governance. The paper goes on to consider the democratic implications of this transition from nation state hegemony to pluricentric governance from the perspective of traditional liberal theories of democracy. Finally, I show how governance networks, seen from the perspective of a new emerging body of theories about democracy, might contribute to enhancing democracy in the age of pluricentric governance by providing an arena for inter-demoi participation and deliberation.

\section{Participation and deliberation in liberal theories of democracy}

Liberal theories of democracy, theories which seek to deal with the tension between collective decision making and individual liberty (Holden, 1993: 23ff; Heywood, 2002: 30), can be divided into two groups: protective and developmental (Heywood. 2002: 73-6; Held, 1987: Ch. $2 \& 3)$. Both groups of theory underline the importance of participation and deliberation for democracy.

Protective theories of democracy regard participation and deliberation as crucial for the protection of the citizens vis-a-vis the state (Mill, 1820/1937: 45; Bentham, 1776/1948: 143; 
Dahl, 1989: 113). Citizen participation in general elections is vital because it grants the citizens a means to control the sovereign ruler i.e. the government through the election of representatives. Deliberation is equally important because it enhances the ability of the citizens to make informed choices at Election Day. Hence, on this view, ongoing public debate in a free public space provides citizens with relevant knowledge and information about the issues at stake, and an opportunity to test and qualify their points of view in dialogue with other citizens and elected representatives. The underlying point of reference in this protective approach to participation and deliberation is that democratic control exclusively concerns the relationship between a specific group of citizens and their elected representatives within a given predefined territorially demarcated demos i.e. the state.

Within protective theories of democracy, the liberal tension between collective decision making and individual liberty appears as a dilemma between 'government by the people' and 'government for the people': should priority be given to ensuring a strong citizen control over the government or to enhancing the ability of this government to govern efficiently and effectively for the benefit of the people? It is believed that there is an inherent trade-off between democracy and efficiency that cannot be resolved. This trade-off is clearer in some policy areas than in others, and most of all in foreign policy, due to the central role of interdemoi interaction between governments (Connolly, 1995: 141). Foreign policy, where the liberal state performs one of its most central objectives, namely that of protecting the citizens against outside dangers and enemies, is said to need a high level of confidentiality in order to be efficient. The price that must be paid for this confidentiality is a restriction of the citizens' ability to control their representatives when they act on the international scene through their access to full information and a free public debate. As such protective theories of democracy tend to give up the call for tight control over governance processes that involve inter-demoi interaction.

Developmental theories of democracy perceive political and participation and deliberation as crucial for the transformation of the citizens from self-interested individuals into democratic citizens who regard themselves as part of a united People with common interests and a shared understanding and identity (Stuart Mill, 1861/1946: 254; Tocqueville, 1835/1968: 25; Almond \& Verba, 1963: 88-9; Pateman, 1970: 105). Democratic citizens do not merely pursue individual goals but seek to promote the common good of the specific demos to which 
they belong. The sense of communality and shared identity that constitutes a strong unitary demos is brought about through the existence of a well functioning civil society that allows for extensive citizen participation and public deliberation. Citizen participation helps to visualize the interrelatedness between individual and collective interests while ongoing deliberation among the citizens enhances the creation of shared understanding and belonging as such a strong civil society is seen as the corner stone of democracy.

In developmental theories of democracy, the tension between collective decision making and individual liberty surface as an insurmountable tension between democratic inclusion and exclusion. Hence, the claim for communality sentiments as a constitutive feature of a demos tends to produce sharp patterns of internal and external exclusion because the development of strong collective points of identification relies on the construction of a constitutive outside that produces antagonistic sentiments between the included and the excluded.

Internally, the constitutive outside is represented by those individuals who have not yet developed into democratic citizens, capable and willing to pursue the common good of the larger community. These individuals should be given access to participating and deliberating in civil society in order to promote their transformation from self-interested individuals into democratic citizens. However, they should not be given influence until this transformation has taken place. John Stuart Mill's famous proposal of a system of plural voting and a democratic divide between a national level of competent democratic decision making and a local training ground for citizen participation and deliberation illustrates this way of thinking, and the resulting search for ways to disconnect participation and influence (Stuart Mill, 1861/1946: Ch. 6; Macpherson, 1977: 50ff). The paradoxical outcome of this desire for a strong collective point of identification within a given demos is the construction of a sharp line of demarcation between the included and the excluded: 1) between those who count as fully developed democratic citizens and those who do not, and 2) between that which has been canonized as being in the interest of the common good and that which has not. Totalitarianism lurks nearby.

Externally, the constitutive outside of the unitary community consists of those who do not belong to the community: those who belong to other communities as well as those who fall in between demoi. By focusing exclusively on the common good of the members of a given unitary community, efforts to relate to a common good that reaches beyond that demos is 
democratically incomprehensible and irrelevant. Efforts to promote collective thinking, shared points of identification and a deep sense of communality through various forms of participation and deliberation stops at the borders of the demos i.e. the nation state, and political issues that transgress the borders of this nation state cannot and should not be regulated democratically. Nationalism lurks nearby.

It should now be clear that both protective and developmental theories of democracy, perceive democracy as a way of regulating decision-making within the confines of a sovereign unitary nation state.

It is important to note that the image of the sovereign unitary nation state, which underpins liberal theories of democracy, is not a mirror of reality. The distance between imaginary and actual political systems is not least evident in federal democracies where the difficulties of theoretically conceptualizing the relationship between the federal government and the states have been persistent (Dahl. 1986: 114). These conceptual difficulties materialize as an ongoing battle between federalists and con-federalists (Deleon, 1997: 14ff), and in the theorizing about consociationalism (Lijphart, 1977) which seeks to deal with the question of intra-demos heterogeneity within multi-leveled and/or socially pillarised societies. The distance between the sovereign state imaginary and reality is also well known in unitary states, which to a larger or smaller degree has been known to allow for some degree of autonomy for selfregulating communities and for participating in international organizations which formally or informally influence national decision making.

However, the massive transformation of the institutional set up of advanced liberal democracies that has taken place in the last decades has deepened the distance between imaginary and reality to a degree that makes references to a unitary sovereign nation state more and more of an anachronism. The persistent survival of the image of a sovereign nation state as the hegemonic point of departure in debates on how policy making is and should be performed is in Bill Connolly's (1995: 317) phrase to be understood as no more than a 'politics of homesickness', which we cling to in order to maintain the safe perception of politics as an orderly and controlled process that is played out within the confines of a given territory conceptualized as 'Community', 'Nation', or 'People'. This politics of homesickness hampers our recognition of the considerable impact that the emergence of a pluricentric political system 
has on the contemporary functioning of democracy, and thus draw our attention away from the pressing need for a theoretical as well as an institutional renewal of democracy.

\section{Towards pluricentrism}

What kind of political system is developing in the wake of the withering of the sovereign nation state? Despite considerable differences between them, political scientists and governance theorists tend to agree that advanced liberal democracies are getting more and more pluricentric (Rhodes, 1997; Kickert, Klijn \& Koppenjan, 1997; Goldsmith \& Eggers, 2002; Ansell, 2000; Kettle, 2002; Kersbergen \& Waarden, 2004; Pierre \& Peters, 2005; Skelcher, 2005; Sørensen \& Torfing, 2007). The increased pluricentrism is seen as a result of four changes.

An emerging process of political globalization has led to the establishment and consolidation of a plurality of transnational political institutions and public and private organizations that push for the codification of a set of transnational standards for how nation states can act internally and externally, and which monitor transnational policy making and policy implementation (Greven \& Pauly, 2000; Bache \& Flinders 2004; Larner \& Walters, 2004; Van Heffen, Kickert \& Thomassen, 2000).

A de-bureaucratization of the administrative apparatus through the implementation of New Public Management (NPM) reforms has split the political system into a fragmented and decentered plurality of self-regulating units of public governance. In doing so, NPM has transformed the role of elected politicians from being sovereign rulers to members of political 'Boards of Directors' who govern at a distance and leave the actual concrete governing processes to public administrators and the involved stakeholders (Hirst, 1994: 7; Rhodes, 2000: 345f; Pollitt \& Bouckaert, 2004: 175; Bogason, 2004: 27 f).

A reinterpretation of private actors such as private businesses and voluntary organizations into co-producers of public governance which takes place through various formal and informal partnership arrangements has undermined the demarcation line between state, market and civil society and thus between the governed and the governing (Kooiman, 1993: 4; Mathur, Skelcher \& Smith, 2004: 2: Milward \& Provan, 1993: 222ff; Kettl, 2002: 119). These partnerships, which function in what could be defined as a 'gray zone' of governance beyond the public and private, are only to some degree controlled by public authorities. 
A severe coordination deficit in pluricentric political systems has triggered an increased interest and acceptance of governance networks as a valuable and legitimate means of public governance. The purpose of such networks is to provide coordination between the large and complex plurality of de-centered and multi-layered public and private producers of public purpose (Kickert, Klijn \& Koppenjan, 1997: 7ff; Rhodes, 1997: 51; Milward \& Provan, 2001: 241; Goldsmith \& Eggers, 2002: 9ff; Ansell, 2000: 305). However, such networks show little interest in where one demos ends and the next begins.

The added outcome of the four elements in the surge of pluricentrism described above is a distortion of the external and internal sovereignty of the nation state (Onuf, 1991: 432; Hinsley, 1986: 100). Political globalization and the establishment of governance networks which disregard the borderlines between different demoi jeopardizes the external sovereignty of the state vis-à-vis other sovereign rulers, while the fragmentation and de-centering of governance competencies to various relatively self-regulating public and private actors and partnerships diffuse the internal sovereignty of the state. Finally, the formation of governance networks blurs the borderlines between different policy compartments and different levels in the political system.

As such, public governance can no longer be seen as the outcome of a system of state rule. Rather, it should be seen as the outcome of complex patchwork-like process of piecemeal decision making that takes place within the confines of a pluricentric political system in which different centers of power within and beyond the state apparatus seeks to govern society in close cooperation and competition with other public and private centers of power.

While most governance theorists agree on a more or less radical version of this diagnosis, debates concerning the impact the surge of pluricentrism has on the position of the state have been harsh. Some argue that the state is a strong as ever (Hirst \& Thompson, 1996; Kernsberger, Lieshout \& Verbeek, 2000), while others contend that the powers of the state have been reduced considerably (Milward \& Provan, 1993). However, a large group of governance theorists, and I with them, argue that the external and internal sovereignty of the state has indeed been reduced, but that this does not necessarily weaken the powers of the state (Mayntz, 2003: 32; Kooiman, 2003: 79; Jessop, 2004: 57; Ansell, 2000: 310). Hence, pluricentrism can be seen as an outcome of a new governmentality (Dean, 1999: 6) that paves the way for an extension of the realm of public governance into the trans-national realm and the private 
realms of the market and civil society, which were formerly beyond the reach of liberal governments (Keane, 2009).

However, this governmentalization of society goes hand in hand with a governmentalization of government itself that calls upon the state to govern in different ways (Dean, 1999: 21, 193). Sovereign forms of rule must be given up in order to strengthen the ability of the state to govern society through forms of governance that are played out through the design of governance processes and political identities that invoke societal actors to govern themselves and others. In sum, the state has lost its sovereign position, while at the same time developed new techniques by which to govern society through the regulation of freedoms (Rose, 1999: 65), or as governance theorists call it, meta-governance (Jessop, 2003; Kooiman, 2003; Sørensen \& Torfing, 2006: chapter 9). Pluricentric governance is an outcome of this double endeavor to enhance the self-regulating capacity of society and the meta-governing powers of the state.

In sum, the age of pluricentric governance has undermined the sovereign position of the state vis-á-vis other centers of political decision making, just as it has transformed the state itself from being a unitary whole into being a fragmented and decentred patchwork of overlapping arenas of public-private co-governance. In this pluricentric political system, coordination is not primarily achieved through formal law and bureaucratic rule and regulation within the limits of a coherent clearly demarcated unit of governance, but through metagovernance and different forms of self-regulation within a complex, dynamic and heterogeneous plurality of relatively autonomous and mutually overlapping units of public governance within and beyond the boundaries of the nation state.

\section{Pluricentrism as a challenge to liberal democracy}

Pluricentrism challenges liberal perceptions of democracy in at least two ways: 1) it undermines the channels of democratic control with elected political leaders that are so central to protective theories of democracy, and 2) it distorts the formation of a unitary homogenous community with a shared identity and a clear image of its constitutive outside that developmental theories of democracy regard as the constitutive feature of democracy.

\subsection{The control problem}


The democratic control problem springs from the fact that governance no longer takes place within a unified political system in which a clearly demarcated body of citizens controls a group of representatives through their informed and qualified participation in general elections that take place on the basis of free public deliberation. This democratic control model is first of all undermined by the fact that pluricentric processes of governance more often than not involve more than one nation state. Inter-state governance is no longer a specific feature of foreign policy but has become an important and increasingly institutionalized ingredient in most areas of public policy making. The fact that these inter-state activities are only to a limited extent controlled by elected politicians and made subject to public deliberation does not necessarily represent a problem for democracy if they, like foreign policy, are seen as a necessary means to provide efficient and effective governance for the people. Seen from a protective approach to democracy, this reduced control could be seen as a necessary and insignificant rebalancing of the insurmountable tension between democracy by the people and democracy for the people. This viewpoint has among other things found its way into the debate on the democratic quality of the EU (Majone, 1998; Moravcsik, 2004). More problematic is the distortion of the protective control mechanisms that takes place when the citizens of many national demoi, as in the EU, have been given the opportunity to elect a trans-national body of representatives. From the perspective of protective theories of democracy, this trans-nationalization of representative democracy is perceived as a serious problem because it undermines the one-to-one relationship between the people and its representatives. Hence, the establishment of a cross-demoi body of elected representatives, like the EU-parliament, paves the way for a situation in which citizens from one demos are ruled by a majority of representatives elected by citizens from other demoi. This situation has resulted in a heated debate about the degree to which democratic thought is in fact at all compatible with trans-national institutions (Scharpf, 2001; Greven 2000; Newman, 2000; Schmitter, 2000; Dahl, 1999).

As such the protective control perspective leads to one out of two reactions to political globalization: 1) an acceptance of an intensified and more institutionalized foreign policy, which is more loosely democratically controlled than national policy making (Majone, 1998; Moravscik, 2004), or 2) a call for the establishment of a cosmopolitan democracy in which the protective relationship between a clearly demarcated citizenry and a sovereign body of elected representatives is upgraded to a global level (Held, 1995; Habermas, 2001; Bohman, 2005). 
Another clash between pluricentrism and the protective control perspective, has to do with the still more decentred and fragmented scope of the state apparatus caused by the New Public Management (NPM) reform programme (Pollitt \&Bouckaert, 2004; Hood, 1991). One of the central elements in the NPM-programme is that it establishes a division of responsibility for public service provision between the elected representatives and various producers of public service. This new division is not immediately comprehensible for the citizens, and it becomes still more difficult for them to establish a clear connection between decisions made by elected representatives and the experienced performance of public service providers. This decoupling of political leadership and public service delivery is recognized and encouraged by the NPMreform programme, which calls upon dissatisfied citizens to blame the service providers, and sanction them and not the politicians by 'exiting' as would a customer on a market (Hirschman, 1970). Hence, the de facto outcome of NPM-reforms is a down-grading of the ability of the citizens to control the public sector through democratically elected representation, and an upgrading of the citizens' ability to sanction public service providers through their new role as costumers on a market. Seen from a protective perspective on democracy this way of ensuring democratic control is not only problematic because it undermines the sovereign control of the elected representatives with substantial parts of public governance, but also because the exitbased market oriented control system is not accompanied by 'voice' mechanisms (Hirschman, 1970: 30), which ensure that citizens are able to make informed and well reflected choices qualified through public participation and deliberation (Sørensen, 1997).

Yet, another control problem related to pluricentrism has to do with the establishment of all sorts of public-private partnerships between public authorities and voluntary organizations and business firms. Such partnerships are problematic because it is difficult for citizens, as well as for elected politicians, to control private actors through participation and deliberation. It is not possible to democratically sanction private actors at Election Day, just as the legalized claim for transparency and openness in processes of public decision making tend to become weaker when private actors are involved.

Finally, the complex web of governance networks that emerge in the effort to enhance vertical and horizontal coordination within the increasingly decentred and fragmented political system are problematic seen form a protective approach to democracy because the informal and dynamic character of governance networks makes them difficult to control. Hence, inter- 
organizational governance networks between public and private actors and between local, national and transnational public authorities tend to de-couple the bureaucratic and legal strings of control through which elected politicians seek to maintain sovereign control over the governance process, and the informality and opaqueness of network interaction reduces the ability of the citizenry to control them by making their actions subject to public deliberation.

In sum, the erosion of the unitary sovereign state caused by the NPM-reform programme, the formation of public-private partnerships, and the surge of inter-organizational governance networks, has severe implications for the exercise of democratic control as defined by protective theories of democracy. The control problem can only be remedied in one out of two ways: 1) through a re-institutionalization of the sovereign state and the patterns of participation and deliberation ensured by the traditional institutions of representative democracy, or 2) through the development of a tight system of metagovernance that ensures elected politicians an indirect control with the many actors that contribute to the production of public governance through the measurement of policy outcomes. This change in focus from input-side democracy (democracy by the people) to output-side democracy (democracy for the people) is a core ingredient of the NPM reform program (Sørensen, 2007).

\subsection{The community problem}

It is now time to take a look at how the emergence of a pluricentric system of governance jeopardizes the promotion of a strong sense of communality so highly valued by developmental theories of liberal democracy. First, political globalization tends to blur the borderlines that demarcate the external patterns of inclusion and exclusion between a given demos and its constituting outside. It simply raises doubts about the scope of the demos: its boundaries, its identity, and its homogeneity. Trans-national political institutions such as the EU and the UN tend to rank both the human rights of individuals and the common good of the globe higher than the well being of the individual nation state. By doing so, they raise doubts as to the political legitimacy of focusing exclusively on the common good of individual nation states just as such institutions promote the production of transnational points of political identification. The result is a destabilization of the image of the nation state as an undivided naturally given political unity that has the legitimate right to pursue its national interests to the benefit of its citizens. As such, the presence of transnational political institutions increase the inherent 
tension already present within developmental theories of democracy between the call for extensive participation and deliberation among all citizens, and the harsh exclusion of noncitizens, by illuminating the contingent and political character of the external patterns of exclusion.

The image of democracy as something that is played out within the confines of a unitary political community is also threatened from within due to the internal decentring and fragmentation of the state apparatus. Hence, the internal transformation of the state apparatus tends to undermine the image of the nation state as one large unitary and undivided national community held together by a strong sense of shared communality and identity. The unitary image is eroded by the emergence of a plurality of partial territorially and functionally demarcated and mutually overlapping publics (Habermas, 1989, 1992; Fraser, 1992) with complex, unclear and relatively unstable points of identification. The consequential weakening of the internal unity within the national demoi leads to a de-legitimization of internal exclusions of those who cannot and/or will not attest to the view point which has gained hegemony as the right perception of the common good. The division of the public into many publics with competing perceptions of the common good, different points of identification and different notions of communality destabilize the very idea, that a unitary communality is a precondition for a well functioning democracy. As such, the presence of many publics and communalities visualizes that the internally excluded are excluded on contingent grounds because they do not fit the prevailing image of what it means to be a good democratic citizen at a given point in time. It becomes clear that exclusions are political in nature and should thus be made subject to democratic regulation.

The propensity to establish clear internal lines of demarcation between the included and the excluded in developmental theories of democracy, is further challenged by the increasing involvement of private actors in the production of public governance. This involvement disrupts the image of organized interests and private businesses as outside the realm of democratic decision making. A developmental approach to democracy regards private actors as carriers of particular interests, wherefore their participation in processes of public governance disrupts efforts to identify the common good. For that reason, only citizens should be included in processes of public governance. 
In sum, the emergence of a pluricentric political system destabilizes the external and internal patterns of exclusion that are central to developmental theories of democracy by making it difficult to develop a stable and unitary sense of communality among a demarcated group of citizens. Polycentrism promotes an unstable scenario of shifting and overlapping territorially and functionally anchored points of collective identification, which constantly calls for the construction and justification of new temporal demoi and related patterns of external and internal inclusion and exclusion.

\section{Governance network as a medium for inter-demoi democracy}

It should now be clear that the surge of a pluricentric political system distorts and destabilizes two core features of democracy as envisaged by liberal theories of democracy: the unitary chain of democratic control installed through the institutions of representative democracy and the production of one over aching national sense of communality.

Against this background, it is tempting to view the future of democracy as gloomy. However, I shall argue that the prospects for democracy are not necessarily that bleak. According to a number of new theories of democracy, the future of democracy depends on its ability to adapt to new circumstances (Hurley, 1999: 276; Benz \& Papadopoulos, 2006: 4; Bohman, 2005: 293; Saward, 2000: 3). These theories do not attempt to identify one true universal and perfect model of democracy that will fit all societies at all times. Instead they take a more modest, pragmatic and innovative stand by claiming that the aim must be to find ways in which to make the best of democracy at this particular time and space in history. The need to be modest and pragmatic is among others stressed by James Bohman when he suggests that the aim of democratic theory must be to focus on democratization i.e. moving in the right direction instead of reaching for the stars (Bohman, 2005), while Mark Saward points to the inherently innovative character of democracy that calls for a constant conceptual and institutional renewal of democracy: 'The story of democracy is nothing if not a story of innovation. One of the defining features of democracy may well be its restlessness, dynamism and comparative openness to new ideas' (Saward, 2000: 3). As such, the future of democracy rests on our ability to creatively adjust and redefine the conceptual and institutional features of democracy in order to increase its ability to function in a changing world. 
One of the core challenges that face democracy in the age of pluricentrism is the extensive amount of governance that involves more than one demos and this situation calls for democratic innovation regarding how to democratically regulate inter-demoi governance. If this pressing need for democratic innovation is met, there is not only a solid chance that democracy will survive pluricentrism - the chances are that democracy will prosper from it. First, the search for ways to promote the democratic quality of inter-demoi interaction might in fact lead to the development of new patterns of participation and deliberation that will help to strengthen intra-demos interaction between elected leaders and citizens. As argued by a number of scholars, institutions of representative democracy have not in practice been able to fulfill the promise made by traditional theories of liberal democracy, namely to establish close links of control and identification between elected representatives and the citizen (Stoker, 2006; Pitkin, 2004; Barber, 1984; Hirst, 2000). By restricting the interaction and communication between decision makers and citizens to participation in general elections and public deliberation in a public sphere dominated by commercial mass media, the links of control and shared identification have become very 'thin'. Various supplementary forms of territorially and functionally organized participation and deliberation that promote an ongoing and intensive interaction and communication between decision makers and citizens might in fact help to strengthen representative democracy. The introduction of such supplementary forms of participation and deliberation will indeed make democracy complex and messy compared to the simplistic and unitary institutions of representative democracy, but the gain is likely to be a much needed improvement of the quality of democratic representation (Pitkin, 2004).

Second, the search for ways to democratically regulate inter-demoi governance initiates a just as needed expansion of the realm of democracy. By viewing democracy as an intrademos phenomenon that has to do with the establishment of links of control and collective identification between elected representatives and citizens, traditional theories of democracy deemed important parts of the governance process beyond the realm of democratic regulation. This narrow perception of the democratic realm deems governance processes that take place at the trans-national level, involve private actors, and deal with the implementation of public policy as democratically irrelevant. As such, the mere extension of the focus of democracy so as to include inter-demoi governance paves the way for an extension of democracy. However, in order to fulfill this promise of a strengthened democracy we need to develop ways in which 
to promote inter-demoi control and communality through different forms of inter-demoi participation and deliberation.

The search for inter-demoi forms of participation and deliberation must go down many avenues in order to cover as much ground as possible. In this paper, however, I restrict my focus to considering the possible role of governance networks. Governance networks are a part of the pluricentric challenge to democracy but they might also prove to be a part of the solution in that they provide a forum for vertical and horizontal coordination, cooperation and communication that has the potential to promote inter-demoi control and identification.

Then, what do I mean by governance networks? Summarizing the definition of governance networks posed by the extensive literature on the subject, governance networks can be defined as 1) relatively stable articulations of interdependent, but operationally autonomous actors, who 2) interact with one another through negotiations, which 3) take place within a regulative, normative, cognitive and imaginary framework, that is 4) self-regulating within limits set by external forces, and which 5) contributes to the production of public purpose (Sørensen \& Torfing, 2007: 8).

Governance network theorists argue that the current growth in governance networks can, among other things, be explained by their ability to provide inter-organizational coordination, which is essential for the production of efficient and effective public governance under pluricentric conditions (Pierre \& Peters, 2005; Sørensen \& Torfing, 2007: Ch. 1). As argued by Jan Kooiman the fragmented and differentiated nature of a pluricentric society (or socio-political system of governance as he calls it) produces long cross-organizational lines of interdependency because efforts to solve concrete governance problems in most cases demand for cross-organizational coordination, cooperation and communication (Kooiman, 2000: 139). Governance networks provide an institutional framework for enhancing negotiated coordination between such 'long lines' of interdependent but operationally autonomous actors.

Empirical studies find that governance networks take many forms. Some networks are loose, inclusive and short lived while others are tight, exclusive and long-lived (Rhodes and Marsh, 1992). Some governance networks are ambitious and target positive coordination through the formulation of shared objectives, while others are less ambitious and settle for negative coordination i.e. seeking to avoid externalities (Scharpf, 1994). Finally, some governance networks seek to enhance vertical coordination between actors at different levels of 
governance, while others target horizontal coordination between different public and private contributors to the production of public governance at a given level of governance (Markussen \& Torfing, 2007).

As indicated above, the focus of attention in governance network theories has been the contributions of governance networks to the efficient and effective production of public governance, and the main conclusion seems to be that governance networks add substantially to the efficiency and effectiveness of public governance. While less attention has been directed towards the possible implications of network governance for democracy, there tends to be a general agreement among governance network theorists that this issue is crucial and needs to be placed high on the research agenda in the years to come. First in this important endeavor, however, is to carefully re-conceptualize the notions of control and communality in order to make these cornerstones of democratic thinking applicable to processes of inter-demoi participation and deliberation. Below, I shall first reconsider the concept of democratic control and discuss how participation and deliberation in governance networks can contribute to the enhancement of inter-demoi control. Next, I turn to the concept of communality and seek to apply it to inter-demoi participation and deliberation within governance networks.

\section{The question of inter-demoi control}

It is about time that we give up the idea that democratic control can be installed in a one-to-one relationship between a democratically appointed authority and a People. If it ever did work as intended by the protective approach to democracy, which I seriously doubt, this one-stringed control mechanism has become insufficient to ensure control in the complex, fragmented, dynamic and patchwork like societies of our time. The imagined one-to-one relationship must give way to an image of democratic control as something that is installed between a plurality of temporarily organized groups of affected individuals and a multiplicity of more or less autonomous functionally and territorially authorized decision makers. This reinterpretation of democratic control indicates two things: 1) that democratic control must be institutionalized through many supplementary control mechanisms, and 2) that the People controlling the decision makers should not be seen as a fixed body of citizens within a nation state but as a temporary body of affected individuals that overlaps with other temporary bodies of affected actors. With regard to the former, the establishment of a complex plurality of control 
mechanisms, although complex and messy, will promote a tighter and more substantive interaction between citizens and decision makers. Regarding the latter, an increased focus on affectedness will serve to fine tune the democratic control mechanisms so as to insure that those who are most strongly affected have access to more control mechanisms than those who are less affected.

In recent years, it has become increasingly clear that degrees of affectedness do not necessarily follow well established lines of demarcation between demoi (Dryzek, 1997, 2007). Therefore, it is time to recognize that effective democratic control mechanisms that grant affected citizens the best possible control with the decision makers calls for the construction of temporal and overlapping demoi organized around concrete degrees of affectedness. In some instances, the nature of the issue at stake calls for territorially organized temporal demoi while in other situation the organizing principle must be functional. Hence, a citizen might at a given point in time belong to one demoi with regard to some aspects of life, while belonging to another demoi when it comes to other aspects, and the membership of each of these demoi gives access to specifically designed democratic control mechanisms.

As such, the increased focus on affectedness as an organizing principle of democracy and the establishment of a plurality of links of control between citizens and decision makers is likely to ensure a considerable level of democratic control in a pluricentric society. However, as originally argued by Charles Montesquieu, and recently rearticulated by Eva Ezioni-Halevy (1993, 2003) democratic control institutionalized through traditional forms of representative democracy is not on its own enough to ensure the citizens an effective democratic control over elected elites since power between citizens and elites tends to become asymmetrical. Accordingly, effective systems of democratic control call for a separation of powers between elected political elites that reduce their respective powers and promote a situation in which elites control elites. Guillermo O'Donnell and others (O'Donnell, 1999; Kenney, 2000) have conceptualized this way of installing democratic control through a separation of powers in terms of horizontal accountability which, by supplementing vertical forms of accountability, contributes to insuring a democratic control with political elites. As argued by O'Donnell (1999: 169) 'accountability runs not only vertically, making elected officials answerable to the ballot box, but also horizontally, across a network of relatively autonomous powers' . 
While Montesquieu called for a separation of powers within the sovereign state, EzioniHalevy advocates an extension of this separation beyond the realm of the nation state. Hence, she points to the importance of a high level of ongoing political competition and contestation between a plurality of autonomous public and private elites and sub-elites for enhancing both horizontal and vertical accountability. While horizontal accountability is ensured though the separation of powers between a wide plurality of political elites within and beyond the state, the vertical accountability, which is partly ensured from below through the ballot box, is further strengthened through the presence of an intermediate level of sub-elites placed between elected political elites and ordinary citizens. The presence of sub-elites, she argues, promotes qualified vertical contestation, competition and mobility between decision makers and decision takers. Vertical accountability, it could be added, is further supplemented from above through the presence of a range of trans-national political institutions, Courts and NGOs, which contest the actions of the Nation States. Seen from this control perspective, the development of a pluricentric political system in which political power is dispersed to elites and sub-elites at different levels and centers of decision making enhances the level of democratic control rather than weakening it.

However, the activation of a system of vertical and horizontal checks and balances, calls for institutionalized arenas in which autonomous political elites and sub-elites can pursue negotiated goals (Lijphart, 1977; Follesdal \& Hix, 2005). This is exactly where governance networks enter the stage as an important instrument for ensuring an ongoing contestation and negotiated cooperation between democratically authorized demoi (Esmark, 2002, 2007). The reason why networks fit this task so well is that they, as described above, consist of operationally autonomous but interdependent actors who decide to coordinate their actions in order to reach negotiated goals. As such, governance networks represent a central means by which to promote coordinated action in situations where hierarchy is not an option as is often the case under pluricentric conditions. It offers to do so by bringing relatively autonomous but mutually interdependent political elites and sub-elites together in a shared effort to reach negotiated policy goals through processes of political contestation and negotiation which are pressed forward by interdependencies founded on the separation of powers (Fung \&Wright, 2003: 23). 
However, in order to give elites and sub-elites the autonomy they need in order to be able to take part in negotiated decision making within governance networks, the patterns of democratic control and accountability must take a more subtle form. If the represented keep their representatives under too tight a leach, governance networks will be unable and unwilling to produce negotiated agreements. Hence, the democratic control of governance networks must be carried out either ex post through intensive public deliberation, evaluation and contestation of the outcomes of governance networks or through horizontal and vertical forms of accountability exercised through the checks and balances within and beyond the governance networks. As such, the next step is to search for ways in which to promote forms of participation and deliberation that enhances proactive and horizontal and vertical forms of control of governance networks.

\section{The question of inter-demoi communality}

Governance networks do not only give promise of the promotion of new forms of inter-demoi control. They also provide a much needed arena for inter-communal participation and deliberation which softens the sharp lines of demarcation between the included and the excluded in traditional understandings and institutionalizations of democracy. It is, in other words, time to realize that the presence of a strong unitary sense of communality is not only positive for democracy but represents a double edged sword: a strong sense of communality produces unity, and unity produces exclusion.

In effect, efforts to promote communality sentiments should be pursued with caution and there should be a search to develop what could be called "soft edges" between the inside and the outside. By the term 'soft edges' I refer to the need to develop agonistic sentiments within and between demoi as opposed to antagonistic sentiments, which by undermine democratic interaction (Connolly, 1996; Mouffe, 1993; Tully, 2000). The goal must be to promote an awareness of the fact that the collective points of identification that glue a demos together as a community, the image of the common good pursued by that demos, and the notions of what it means to be a good citizen it prescribes are no more than a contingent outcome of political decisions, and has no higher justification than that. This recognition of the contingency of political communities, notions of the common good and images of legitimate democratic identities is important because it promotes the acceptance of difference as 
something that is to be dealt with within the realm of democratic decision making and not beyond it through extensive internal and/or external exclusion. Exclusions are inevitable and a constituting feature of political decision making, but we need to acknowledge their political nature, and ensure that the process through which exclusions are decided is democratically regulated.

The central task is then to uncover how antagonistic sentiments are promoted. The answer to this question is twofold: 1) through the shaping of situations in which citizens belong to more than one political community, and/or 2) through intensified communication and collaboration between actors which subscribe to different political identities either within a given demos or across demoi. The democratic promise of the age of pluricentrism is that it enacts overlapping citizenry. As described by Michael Sandel (1996):

politics today is played out in a multiplicity of settings from neighborhoods to nations to the world as a whole (...) The civic virtue distinctive to our time is the capacity to negotiate our way among sometimes overlapping, sometimes conflicting obligations that claim us, and to live with the tension to which multiple loyalties give rise. This capacity is difficult to sustain, for it is easier to live with the plurality between persons than within them'. (Sandel, 1996: 350)

The strength of governance networks is exactly that they can enhance the capacity of citizens to deal with plural points of identification between themselves and others as well as within themselves, and hence contribute to the development of what could be denoted pluricentric citizenship calls. Hence, governance networks pave the way for a promotion of inter-demoi communication between autonomous but partially overlapping, interdependent political identities and images of communality. With Mark Granovetter's old terms networks are capable of establishing weak ties of communality between strong ties of unitary communality (Granovetter, 1973: 1369). The same line of argument characterizes the debate on the ability of networks to promote social capital not only through bonding but also through bridging (Putnam, 2000; Hazleton \& Kennan, 2000). In other words, networks can function as a platform for inter-community participation and deliberation that promotes the construction of weak images of communality between communities held together by more dense communality 
sentiments. By doing so, governance networks support the construction of a weak form of interdemoi communality that makes the democratic interaction between demoi possible, while simultaneously reducing the closure of strong intra-demoi-communality that tends to produce intra-demoi exclusion, by illuminating its contingent foundation.

\section{Conclusion}

The emergence of an age of pluricentrism definitely challenges the traditional liberal conceptions and institutionalizations of democratic control and communality and the patterns of participation and deliberation that were meant to enforce them. Since democracy is no longer, if ever, merely an intra-demos phenomenon, we need to re-conceptualize and re-institutionalize patterns of democratic participation and deliberation in ways that promote inter-demoi control and communality. Governance networks have a crucial role to play in this respect kin that the have the potential to institutionalize contestation, negotiation and cooperation between a plurality of elites and sub-elites and to establish weak ties of communality between demoi based on strong ties, and thus to maintain some level of openness and heterogeneity in the collective points of identification within the individual demos.

However, governance networks are no panacea. In order to serve as a means to enhance democracy they must be democratically anchored in different ways. As I and Jacob Torfing suggest elsewhere (2005) governance networks should be democratically anchored by means of four anchorage points: 1) through metagovernance carried out by elected political leaders within the traditional institutions of representative democracy at different levels in the multi-leveled political systems; 2) through different pro-active forms of representation in the various affected groups of stakeholders; 3) through public contestation and deliberation in a wider citizenry and vis-à-vis other networks of elites and sub-elites; and 4) through the presence of a democratic network constitution that includes rules and norms for the external and internal inclusion and exclusion of network actors and for the handling of conflicts within the network (Young, 2000; Sørensen \& Torfing, 2005). The next step in the effort to develop governance networks into a democratic form of participation and deliberation is to develop criteria for the democratic anchorage of governance networks. 


\section{References}

Almond, G. A., and Verba, S. (1963) The Civic Culture (Princeton, Princeton University Press).

Ansell, C. (2000) 'The Networked Polity: Regional Development in Western Europe', Governance. An International Journal of Policy and Administration, 13 (3), pp. 303-33.

Bache, I. and Flinders, M. F. (eds) (2004) Multi-level Governance (New York, Oxford University Press).

Barber, B. (1984) Strong Democracy. Participatory Politics for a New Age (Los Angeles, University of California Press).

Bentham, J. (1776/1948) An Introduction to the Principles of Morals and Legislation (New York, Hafner).

Bentham, J. (1843/) Collected Works (Ed.) Bowring. London.

Benz, A., and Papadopoulos, Y. (eds.) (2006) Governance and Democracy. Comparing National, European and International experiences (New York, Routledge).

Bogason, P. (2004) 'Local Democratic Governance: Allocative, Integrative or Deliberative?' in P. Bogason, S. Kensen, and H. T. Miller (eds), Tampering with Tradition. The unrealized Authority of Democratic Agency (Lanham, Lexington Books) pp. 23-8.

Bogason, P., and Zølner, M. (Eds), (2007) Methods in Democratic Network Governance (Basingstoke, Palgrave Macmillan).

Bohman, J. (2005) 'From Demos to Demoi: Democracy across Borders', Ratio Juris, 18 (3), pp. 293-314.

Connolly, W. E. (1995) The Ethos of Pluralization (Minneapolis, University of Minnesota Press).

Dahl, R. A. (1986) 'Power as the Control of Behavior', in S. Lukes (ed.), Power (Oxford, Blackwell) pp. 37-58.

Dahl, R. (1989) Democracy and its Critics (New Haven, Yale University Press).

Dahl, R. (1999) 'Can International Organizations be Democratic?', in I. Shapiro and C. Hacker-Cordón (eds), Democracy's Edges (Cambridge, Cambridge University Press) pp. 19-37.

Dean, M. (1999) Governmentality - Power and Rule in Modern Society (London, Sage).

Deleon, P. (1997) Democracy and the Political Sciences Albany: State University of New York Press.

Dryzek, J. S. ‘Transnational Democracy’, Journal of Political Philosophy, 7 (1) pp. 30-51.

Dryzek, J. S. (2007) 'Networks and Democratic Ideals: Equality, Freedom and Communication', in E. Sørensen and J. Torfing (eds) Theories of Democratic Network Governance (Basingstoke, Palgrave Macmillan) pp 262-273.

Esmark, A. (2002) At forvalte Europa - Den Danske Centraladministrations Omstilling til det Europaiske Samarbejde, Ph.d-thesis, Institute of Political Science, University of Copenhagen.

Esmark, A. (2007) 'Democratic Accountability and Network Governance - Problems and Potentials' in E. Sørensen and J. Torfing (eds) Theories of Democratic Network Governance (Basingstoke, Palgrave Macmillan). Ch. 16.

Etzioni-Halevy, E. (1993) The Elite Connection: Problems and Potential of Western Democracy (Cambridge, Polity Press). 
Etzioni-Halevy, E. (2003) 'Network Governance as a Challenge to Democratic Elite Theory', Paper presented at the Conference on Democratic Network Governance, Centre for Democratic Network Governance, Roskilde University.

Fraser, N. (1992) 'Rethinking the Public Sphere: A Contribution to the Critique of Actually Existing Democracy', in C. Calhourn (ed.) Habermas and the Public Sphere (Cambridge, Massachusetts, MIT Press) pp. 109-42.

Follesdal, A. \& Hix, S. /(2005) 'Why There is a Democratic Deficit in the EU: A Response to Majone and Moravcsik’ European Governance Papers no. C-05-02.

Fung, A. \& Wright, E.O. (Eds) (2003) Deepening Democracy. Institutional Innovations in Empowered Participatory Governance London: Verso.

Goldsmith, S. and Eggers, W. D. (2002) Governing by network. The New Shape of the Public Sector (Washington D. C. Brookings Institution Press).

Granovetter, M. S. (1973) 'The strength of Weak Ties', American Journal of Sociology, (78) 6, pp. 1360-80.

Greven, M. T. (2000) 'Can the European Union Finally Become a Democracy?', in M. T. Greven and L. W. Pauly (Eds), Democracy beyond the state? The European Dilemma and the Emerging Global Order (Lanham, Maryland, Rowman \& Littlefield Publishers, INC) pp 35-63.

Greven, M. T., and Pauly, L. W. (Eds) (2000) Democracy beyond the state? The European Dilemma and the Emerging Global Order (Lanham, Maryland, Rowman \& Littlefield Publishers, INC).

Habermas, J. (1989) The Structural Transformation of the Public Sphere: An Inquiry into a Category of Bourgeois Society (Cambridge, Mass., MIT Press).

Habermas, J. (1992) 'Further Reflections on the Public Sphere', in C. Calhourn (ed.) Habermas and the Public Sphere (Cambridge, Massachusetts, MIT Press) pp. 442-61.

Habermas, J. (2001) The Post-national Constellation (Cambridge MA, MIT-Press).

Held, D. (1987) Models of Democracy (Cambridge, Polity Press).

Held, D. (1995) Democracy and the Global Order: From the Nation State to Cosmopolitan Governance (Cambridge, Polity).

Hendricks, F. and Musso, J. (2005) 'Making Local Democracy Work: Neighborhood-Oriented Reform in Los Angeles and Duch Rabndstad' in in P. Bogason, S. Kensen, and H. T. Miller (Eds), Tampering with Tradition. The unrealized Authority of Democratic Agency (Lanham, Lexington Books) pp. 39-63.

Heywood, A. 2002 Politics. 2nd edition (New York, Palgrave).

Hinsley, F. H. (1986) Sovereignty (New York, Cambridge University Press).

Hirschman A. O. (1970) Exit, Voice and Loyalty. Responses to decline in firms, organizations and states (Cambridge, Massachusetts, Harvard University Press).

Hirst, P. (1994) Associative Democracy. New Forms of Economic and Social Governance (Cambridge, Polity Press).

Hirst, P. (2000) 'Democracy and Governance', in J. Pierre (ed.), Debating Governance (Oxford, Oxford University Press). 
Hirst, P. and Thompson, G. (1996) Globalization in Question (London, Polity Press).

Holden, B. (1993) Understanding Liberal Democracy (New York, Harvester).

Hood, C. (1991) 'A Public Management for All Seasons?' Public Administration, 69 (1), pp. 1-19.

Hood, C. (1996) 'Exploring Variations in Public Management Reform of the 1980s', in H. Bekke, J. Perry, and T. Toonen (eds), Civil Service Systems in Comparative Perspective (Bloomington, IND, Indiana University Press).

Hurley, S. (1999) 'Rationality, Democracy and the Leaky Boundaries: Vertical vs. Horizontal Modularity', in I. Shapiro and C. Hacker-Cordón (Eds), Democracy’s Edges (Cambridge, Cambridge University Press).

Jessop, B. (1998) 'The Rise of Governance and the Risk of Failure: The Case of Economic Development', International Social Science Journal, 50 (155), pp. 29-45.

Jessop, B. (2003) 'Governance and Meta-governance: On Reflexivity, Requisite Variety and requisite Irony', in H. P. Bang Governance as Social and Political Communication (New York Manchester University Press).

Jessop, B. (2004) ,Multi-Level Governance and Multi-level Metagovernance', in I. Bache and M. Flinders (eds), Multi-level Governance (New York, Oxford University Press).

Kenney, C.D. (2000) ,Reflections on Horizontal Accountability: Democratic Legitimacy, Majority Parties and Democratic Stability in Latin America, Paper presented at conference on Institutions, Acountability and Democratic Governance in Latin America, Kellogg Institute of International Studies, University of Notre Dame, May 8-9 2000,

Kersbergen, K., Lieshout, R. H., and Verbeek, B. (2000), 'Institutional Change in the Emerging European Polity', in O. v. Heffen, W. J. M. Kickert and J. J. A. Thomassen (eds), Governance in Modern Society (Dordrecht, Kluwer Academic Publishers).

Kersbergen, K. V., and Waarden, F. V. (2004) ' Governance' as a Bridge Between Disciplines: Cross-Disciplinary Inspiration Regarding Shifts in Governance and Problems of Governability, Accountability and Legitimacy', European Journal of Political Research, 43 (2), pp. 143-71.

Kettl, D. (2002) The Transformation of Governance. Public Administration in the twenty-first Century, America (Baltimore The Johs. Hopkins University Press).

Kickert, W. J. M., Klijn, E. H., and Koppenjan, J. F. M. (eds) (1997) Managing Complex Networks (London, Sage).

Kooiman, J. (ed.) (1993) Modern Governance. New Government-Society Interactions (London, Sage).

Kooiman, J. (2000) 'Societal Governance: Level, Modes and Orders of Social-Political Interaction', in J. Pierre (ed.), Debating Governance. Authority, Steering and Democracy (Oxford, Oxford University Press), pp. 138-64.

Kooiman, J. (2003) Governing as Governance (London, Sage).

Larner, W and Walters, W. (Eds) (2004) Global Governmentality: Governing International Spaces (London, Routledge).

Lijphart, A. (1977) Democracy in plural societies. A comparative Exploration. New Haven: Yale University Press. Macpherson, C. B. (1977) The Life and Time of Liberal Democracy (Oxford, Oxford University Press).

Majone, G. (1998) 'Europe's 'Democratic Deficit'’ The Question of Standards, European Law Journal 4 (1): 5-28 
Markussen, M. and Torfing, J. (eds) (2007) Democratic Network Governance in Europe (Basingstoke, Palgrave Macmillan).

Mathur, N., Skelcher, C., and Smith, M. (2004) Effective Partnership and good Governance: Lessons for Policy and Practice (Birmingham, School of Public Policy).

Mayntz, R. (2003) 'New Challenges to Governance Theory', in H. Bang (ed.), Governance as Social and Political Communication (Manchester, Manchester University Press).

Mill, J.S (1820/ 1937) An essay on Government /Ed. E. Barker (Cambridge).

Mill, J. S. (1861/1991) Considerations on Representative Government (New York, Prometheus Books).

Milward, H. B., and Provan, K. (1993) 'The hollow state: Private Provision of the Public Sector', in H. Ingram and S. R. Smith (eds), Public policy for Democracy (Washington, Brookings Institutions) pp. 222-37.

Milward, H. B., and Provan, K. (2000) 'Do Networks Really Work? A Framework for Evaluating Public-Sector Organizational Networks', Public Administration Review, 61 (4), pp 601-13.

Moravscik, Andrew (2004) 'Is there a 'Democratic Deficit' in World Politics? A Framework for Analysis' Government and opposition 39 (2): 336-363.

Mouffe, C. (1993) The return of the political (London, Verso).

Newman, S. (2000) 'Globalization and Democracy', in M. T. Greven and L. W. Pauly (eds), Democracy Beyond the State. The European Dilemma and the Emerging Global Order (Lanham, Maryland, Rowman \& Littlefield Publishers, INC) pp.15-35.

Onuf, N. (1991) 'Sovereignty: Outline of a Conceptual History’, Alternatives, 16, pp. 425-46.

Pateman, C. (1970) Participation and Democratic Theory (New York, Cambridge University Press).

Pierre, J., and Peters, B. G. (2005) Governing Complex Societies: Trajectories and Scenarios (London, Palgrave Macmillan).

Pitkin, H. F. (2004) 'Representation and Democracy: Uneasy Alliance', Scandinavian Political Issues, 27 (3), pp. $335-42$

Pollitt, C., and Bouckaert, G. (2004) Public Management Reform. A Comparative Analysis (New York, Oxford University Press).

Rhodes, R. A. W. (1997) Understanding Governance: Policy Networks, Governance, Reflexivity and Accountability (Buckingham, Open University Press).

Rhodes, R. A. W. (2000) 'Governance and Public Administration' in J. Pierre (ed.) Debating Governance. Authority, Steering and Democracy (New York, Oxford University Press) pp. 54-90.

Rhodes, R. A. W., and March, D. (1992) 'New Directions in the Study of Policy Networks', European Journal of Political Research, 21 (1-2), pp.181-205.

Rose, N. (1999) Powers of Freedom: Reframing political thought (Cambridge, Cambridge University Press).

Sandel, M. J. (1996) Democracy's Discontent - America in Search of a Public Philosophy (Cambridge, Harvard University Press).

Saward, M. (2000) Democratic Innovation: Deliberation, Representation, and Association (Routledge, London). 
Scharpf, F. W. (1994) 'Games Real Actors Could Play: Positive and Negative Coordination in Embedded Negotiations', Journal of Theoretical Politics, 6, (1), pp. 27-53.

Scharpf, F. (2001) 'Notes Towards a Theory of Multilevel Governing in Europe', Scandinavian Political Studies, 24 (1), pp. 1-26.

Schmitter P. C. (2000) 'Designing a democracy for the Euro-polity and Revising Democratic Theory in the Process', in I. Shapiro and S. Macedo (eds), Designing Democratic Institutions (New York, New York University Press).

Skelcher, C. (2005) 'Jurisdictional Integrity, Polycentrism, and the Design of Democratic Governance', Governance, 18 (1), pp. 89-110.

Stoker, G. (2006) Why Politics Matters (Basingstoke, Palgrave Macmillan).

Sørensen, E. (1997) 'Democracy and Empowerment', Public Administration, (75) 3, pp. 553-67.

Sørensen, E. (2006) 'Metagovernance: The Changing Role of Politicians in Processes of Democratic Governance', American Review of Public Administration, 36, pp. 79-97.

Sørensen, E and Torfing, J (2005) 'The democratic Anchorage of Governance Networks', Scandinavian Political Studies, 28 (3), pp. 195- 218.

Sørensen, E., and Torfing, J. (eds) (2007) Theories of Democratic Network Governance (Basingstoke, Palgrave Macmillan).

Tocqueville (1968/1835) Democracy in America (London, Fontana).

Torfing, J. (2005) 'Governance Network Theory: Towards a Second Generation', European Political Studies, 4, pp. $305-315$

Tully, J. (2000) 'The Politics of Recognition', Working Paper Series, University of Essex.

Van Heffen, O., Kickert, J. M., and Thomassen, J. A. (eds) (2000) Governance in modern society. Effects Change and Formation of Government Institutions (Dordrecht, Kluwer Academic Publishers). 